\title{
Richard W. Unger Talks Ships, Beer, and Shop for Today's Historians
}

\author{
Interview with Richard W. Unger \\ Recorded: June, 2014 (unaired due to technical problems)
}

Richard W. Unger, originally hailing from West Virginia, is Professor Emeritus of Medieval History at the University of British Columbia. He is an expert on ships and shipbuilding in the Middle Ages and Early Modern period and, therefore, an expert on the emerging trade routes and networks that brought about our current era of globalization. He's also an expert on beer as evinced by his publication of Beer in the Middle Ages and Renaissance (2007), which was rightly described by both Choice and the Medieval Review as "an important book." Students everywhere would agree. The book points to the evolution of the beverage in the Middle Ages and the societal, nutritional, and economic roles it played. As no small recognition of his achievements, he was made president of the Medieval Academy of America in 2013, guiding it and its renowned flagship publication, Speculum, into the brave new world that is medieval studies at present.

Professor Unger was kind enough to join Chris Mielke for a wonderful interview that recorded some very interesting exchanges on the many topics of his expertise. Imagine, then, our horror when we discovered that the sound file of the recording was corrupted. The second part was marred by a horrible screeching sound - one which we assure you was unrelated to either the interviewer or interviewee. However, as you will see in this transcript, it really is a delightful example of a varied and insightful conversation, courtesy of a (very well) established academic. So, regardless of the sound quality problems that prevented an earlier airing of it in our Past Perfect! series, we have chosen to include this very special interview for our volume. 


\section{Shipbuilding and Shipwrecks}

CM: There's a lot that we could potentially talk about, but one of the things I would be particularly interested in, starting the discussion off with, is medieval technology, particularly as it pertains to shipbuilding. Can you tell us a little about some of your work regarding that, if you don't mind?

RU: No, not at all. When I began to look at medieval economic history and at connections, transportation, trade, exchange over some distance, I realized that the vehicles for the moving of the goods were important, and that came just at the moment that underwater archaeology became a real possibility. There were ships, scuba gear, digs in the Mediterranean followed by some digs in Northern Europe, where scuba gear wasn't really used that much because it's hard to see in many Northern European waters. Plus, it's cold. It's not as much fun to dive.

\section{CM: I would imagine!}

RU: With those two things together, suddenly there was... Oh! And it was interesting enough, and the method was novel enough that there was funding for these explorations. And so entirely new information became available. The wonderful thing about ship archaeology is that if you find one, you get this world caught in a moment. One moment in time - a real cross-section of life. So, you could tell things about how people dressed, what they ate, what goods were shipped, and above all, what kind of vessel the goods went in. As each new dig came along, it was possible to make comparisons and to see the development. There had been a long history and discussion of shipbuilding and ship design and its evolution in the Middle Ages and Early Modern period. A fascination because after all Europeans developed some kind of ship that could sail around the world at the end of the fifteenth, beginning of the sixteenth century. They had this thing that nobody else had ever had before and they did it. So, it was possible to take that earlier scholarship based on descriptions and illustrations, put that together with the archaeology, and say some new things about ships and shipbuilding. So, it was a time when new things were really developing thanks again to archaeology, which has 
increasingly become the source for new ideas and new directions in medieval economic history, material culture, many aspects of medieval life.

CM: With some of the work that you've done, I had the good fortune of reading one article of yours that talked about the importance of contact between Iberia and the Low Countries in terms of ship-building technology in a time period where they are not supposed to be the best of friends. What exactly is going on there?

RU: In one way, it's not surprising that there should be exchange of technology. These ships go back and forth. The sailors see these other vessels, vessels can be sold, they can be deserted (nobody wants them anymore), and the information on the construction and design of these ships gets moved around relatively easily. On the other hand, shipbuilders are conservative people. They don't like to take chances. Costs of mistakes are high. Sailors don't like to take chances. They are less likely to take on risk because, after all, it's their lives that are on the line. And shipwrecks are a common thing - the vessels aren't reliable or big enough to handle the seas that these vessels often run into. So, I think going on underneath any kind of conflicts - political, religious differences, social, linguistic - there is an exchange of information that's always active. And as ships improved in design, they could go further, visit more ports farther away. More information got spread around. Then the question was, "Do we try what those guys are doing? Do we give that a shot, or do we stick with what we do?" And that's of course one of the most interesting questions about this precise history of technology and the history of technology in general. Why do people accept one way of doing things and not another? Why do some catch on and others not? Why do some remain? Why do some people stick with old ways of doing things when there seem to be much superior methods around? You can find cases of all those things; retention, rapid change, adaptation, and melding of technologies. You find all those things with medieval ships.

CM: In terms of the finds that are unearthed from a lot of these shipwrecks that are now being discovered, what exactly does an average shipwreck look like? 
RU: Oh, I'm afraid there's no average! Well, I shouldn't say that. There's always an average, but the variation is tremendous. There can be things as simple as a pattern in the earth. The Sutton Hoo ship burial for example, ${ }^{1}$ one of the most famous early medieval ships, was nothing but an imprint in the mud because all the planks had rotted. The other extreme is say the $V a s a,{ }^{2}$ a Swedish warship built (I'm sorry to say) by Dutch shipwrights, which was sent out by the government, insisting that it sail even though the shipbuilders told them it was dangerous to go out and needed some modifications. But for political reasons it had to sail, so it went out into Stockholm harbor and went down on its first voyage. It made a turn and sank. Completely intact and raised intact and still maintained intact in a museum in Stockholm - a beautiful, new museum, very well done. There you can literally see and (if you're as lucky as I was!) walk on and in what was the home of hundreds of men in the early seventeenth century. So, it's everything in between. Usually these vessels will settle on the bottom. They would lose their rigging because of the currents and the rigging tends to rot. The ship itself might well sink down because it was heavy (if the bottom were sandy) and then be covered by sand. So then it would be preserved to some degree. If it did not settle evenly, then some parts might be washed away, and other parts might be preserved leaving you with half of a ship or a piece of a ship. If it was sunk in battle, then there could be bits that get blown off or burnt up before it went down. Smaller vessels, vessels in inland seas, vessels in areas of sandy or muddy soils (essentially much of Scandinavia, the Low Countries and eastern England), there ships tend to be preserved more. In the Mediterranean, [ships] can be preserved but the water is warmer so there's the danger of little beasts eating up the wood. In the north it's colder and ships are typically better preserved. There's the case of two vessels that went down in Lake Ontario in the War of 1812. The only damage to them thus far was from a television camera which was sent

\footnotetext{
${ }^{1}$ Sutton Hoo in Suffolk was the site of the discovery of two sixth- and seventhcentury cemeteries where many Anglo-Saxon period artifacts have been unearthed including an undisturbed ship from the early seventh century.

${ }^{2}$ The $V$ asa was an impressive, but not seaworthy, vessel commissioned by King Gustavus Adolphus of Sweden. It capsized and sank in 1628 during its maiden voyage, shortly after embarking in Stockholm harbor.
} 
down to take pictures of them. Otherwise they're in absolutely pristine condition because Lake Ontario is so cold.

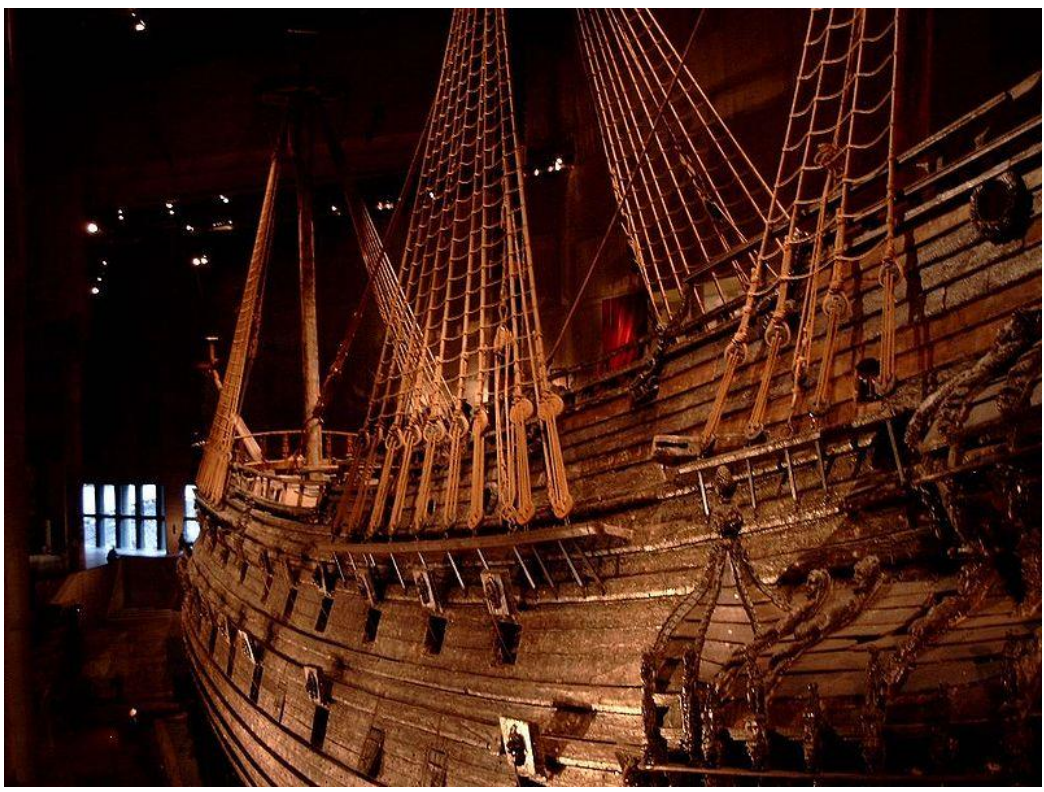

The Vasa Ship (Stockholm Vasamuseet). (Photo by Georg Dembowski, source: https://commons.wikimedia.org)

CM: Right! I had the good fortune two months ago of seeing the Mary Rose, and one of the key advertisements of it was that because the Mary Rose $^{3}$ - in my understanding - fell on its side, part of it was salvaged or taken up back in the Tudor period, but there was a good half of the ship that was still left intact, including the crow's nest. One of the advertisements of the museum was that it had the only Tudor-era crow's nest left surviving.

RU: Yeah, it would be very rare because anything above the deck would probably go if it went down. And you're right, the reason it survived was that the ship was on its side, so the mast actually went down in the mud

3 The Mary Rose was a ship of Henry VIII's fleet, which sank in 1545 near the Isle of Wight during fighting with a French invasion fleet. 
and got saved. This raises two questions. We have this shipwreck: you can study it, you can photograph it (now very extensively), you can measure it using lasers, you can get all kinds of massive detail about the vessel. But then, what do you do with it? You could bury it again, which is often what happens, say, in the Netherlands because there's just not enough money or time to do full-scale excavations. So, you can leave it there. It's lasted five hundred years; another hundred won't matter much. You can dig it up and take it up to a museum and preserve it. Preservation is going to be incomplete. You can try to freeze-dry it. The simplest solution is to fill it with polyethylene glycol. The other principle use of polyethylene glycol is for lipstick. So, it makes for a rather slippery surface, but it does fill in the parts that have rotted, so you maintain the shape and the form of the ship, but you don't get all of it. In the case of the Mary Rose, you get half of it.

With some Viking ships excavated in Roskilde fjord, you get everything from one or two bits to almost the complete vessel. What do you do about the parts that aren't there? Do you try to recreate them? That was what was done into the 1920s. The archaeologists would just know based on what they saw. They could figure out what the rest of the ship looked like. They put new wood in and that was that. New wood does not hold up as well as the old wood, even though the old wood can be up to a millennium old. More recently the solution is to just leave an outline. So, you get a sense, either through pieces of wood or metal, of the shape of the rest of the ship, but there is no effort to try to recreate any of the details. Which is better? Certainly, a fully reconstructed ship is more impressive, and you can see what it was like, but a reconstruction is never the real thing. Mistakes are made. The cog (Bremer Kogge), dated to around 1380 that was discovered in 1962, when some work was being done in the harbor in Bremen, was reconstructed (as I remember) three times. They put it together. There was a lot of it left. They could not take it up in one unit, so they had to take it up in pieces. This often happens - it's very hard to transport one of these things. They put the pieces back together and got about halfway through and realized that it wasn't right, so they had to take it apart and try again and got it right this time. But it is very complete. You really do get an excellent idea of what the ship was like. Even with all of those pieces, if you can't get it right the first time, then recreating parts that you don't know anything about really is guesswork - that's playing with trouble. 
CM: It's definitely a problem. One of the things that I've come to discover is that for a lot of medieval monuments, when I go take my parents around certain monuments - you do a little bit of digging and you find old photos and can see how the site looked in the 1920s, in the 1950s.At certain sites in Budapest, I can think of three different sites where, like clockwork, there's a new renovation done at the site. There's something new put in, and something else that has to be done because, well, the previous people sort of messed this thing up and it's causing more damage to the original structure, and we will have to re-do it. "But this time we will be putting in brick tiles and it will be great and pretty!" And then twenty years later, brick tiles are awful, and everyone hates them.

RU: Yes. Presumably, we always think we're better than the last guys who did this.

CM: Quite.

RU: And in our case, there might be something to it. Computers help. We can do a lot of modeling now that you couldn't do before. So, you can make mistakes on a computer screen rather than doing damage to the original. And materials - we have a lot of different materials that can be shaped, so you're not stuck with just tiles but all kinds of plastics, which you can make into any form, and various woods. So, it's better. But we still have got a curator, undoubtedly well-prepared and knowledgeable, but who has his or her own ideas about how things should be done based on his or her own experience of the time and what they're after. There was a boom in the 1990s, and I think it hasn't gone away in the study of museums and how things are represented. It didn't take much to find the politics or political ideas of the time lie behind whatever renovations, reconstructions, presentations were made in museums. The Middle Ages is not immune from it by any means. Not in as bad of a position as say twentieth or nineteenth-century history, and especially in places where the condition of the nation-state is somewhat in doubt. There things can be touchier. But as I say, the Middle Ages is not immune from it. 
CM: No, indeed, and for a lot of European countries, their origin (or what is perceived as their origin) can be traced back to the Middle Ages.

\section{Beer and Medieval Drinking Habits}

CM: Now I first heard about your name several months ago (although I didn't realize it) because there was an article of yours in a Festschrift dedicated to János Bak about beer in Eastern Europe in the Middle Ages. ${ }^{4} \mathrm{I}$ did a little bit more digging and saw that you've written two books about beer in the medieval Low Countries. I can understand the importance of wine in the Middle Ages, especially in regard to its use in the Eucharist and performing the sacraments. Did beer have as much a significance as wine in the Middle Ages in that regard?

RU: Beer had religious significance, although there were differences. There's the case of the Bishop of Trondheim in Norway, who wrote a letter to the pope in 1237. "Dear Pope, it's really hard to get wine here in Norway." This is the thirteenth century, and the climate was a little warmer but still it's Norway. "It's really hard to get wine. Can we use beer for the Eucharist instead of wine?" The pope obviously wrote back and said, "Absolutely not! Under no circumstances." So, beer never took on the religious significance that wine had. After all, Christianity did originate in the Eastern Mediterranean, a wine region. There is almost no record for beer consumption around the medieval Mediterranean, but in the Roman Empire, in the countryside, the Celts - the word beer is Celtic in fact, not German - would brew beer in France, in Spain, in Italy, also in the days of the Roman Republic and in the early days of the Empire. But because it was in the countryside, it was very simple stuff. For the Romans, there's little or no evidence of making beer in cities. Wine was the standard source of alcohol in the Roman Empire, while in the Middle Ages beer consumption expanded in the geographical area. The drink evolved through the Middle Ages. It's food. We think about beer as an occasional drink.

4 "Beer in Eastern Europe in the Middle Ages," ...The Man of many Devices, Who Wandered Full Many Ways... Festschrift in Honor of János M. Bak, ed. Balázs Nagy and Marcell Sebők (Budapest: Central European University Press, 1999), 294-302. 
CM: Some more occasional than others!

RU: An occasional drink designed for parties, often associated with sports events and young people who don't know what their limit is. That was not the case in the Middle Ages. Average beer consumption even in industrialized countries varies considerably but, oh... seventy-five or a hundred liters of beer per person per year. I can't remember the exact numbers for, say, Hungary or Ireland (which is the second highest beer consuming country in the world - it used to be Belgium, but Belgian beer consumption has gone down recently). In medieval cities, in the fifteenth-sixteenth century, beer production would have been about 250 liters per person per year on average. So, almost four times as much as consumption now. It was much more part of the diet, and it was for everybody. Now it has a reputation as a young man's drink, but in the Middle Ages, it was a breakfast drink for small children. It was certainly what someone had for lunch or dinner. You couldn't drink it all the time, especially if you were too poor to have beer, but in the countryside, if you could afford it, and you had some spare grain, you could make beer. You could buy some beer from a neighbor who had extra, and in towns there were pubs or taverns or women who would sell beer. In some villages, there would be a system where you could go to a single place and make your beer on a Wednesday afternoon, while your neighbor could go on a Thursday evening. Beer is, after all, bread with a lot of water added, and you have to sit around long enough for it to ferment. It doesn't have the nutritional value that bread has due to the added water, but still it has some. Considerably more than coffee or tea or spirits, which replaced beer in the seventeenth and eighteenth centuries, and by 1800-1820, the levels of beer consumption were down to about where they are now, more or less.

CM: There are a couple of points I wanted to talk with you about - and I do want to ask you later on about the alewives - but I think one point that really needs to be drawn out is the question of spoilage. In your work, one of the things that you point out is that with the addition of hops, beer can last up to six months without spoiling, which is something I always find so hard to conceptualize. But in the Middle Ages, food spoils much more quickly than today, I think. How to make your 
resources last as long as possible is really a question of utmost concern well until the 1800s that you just mentioned a second ago.

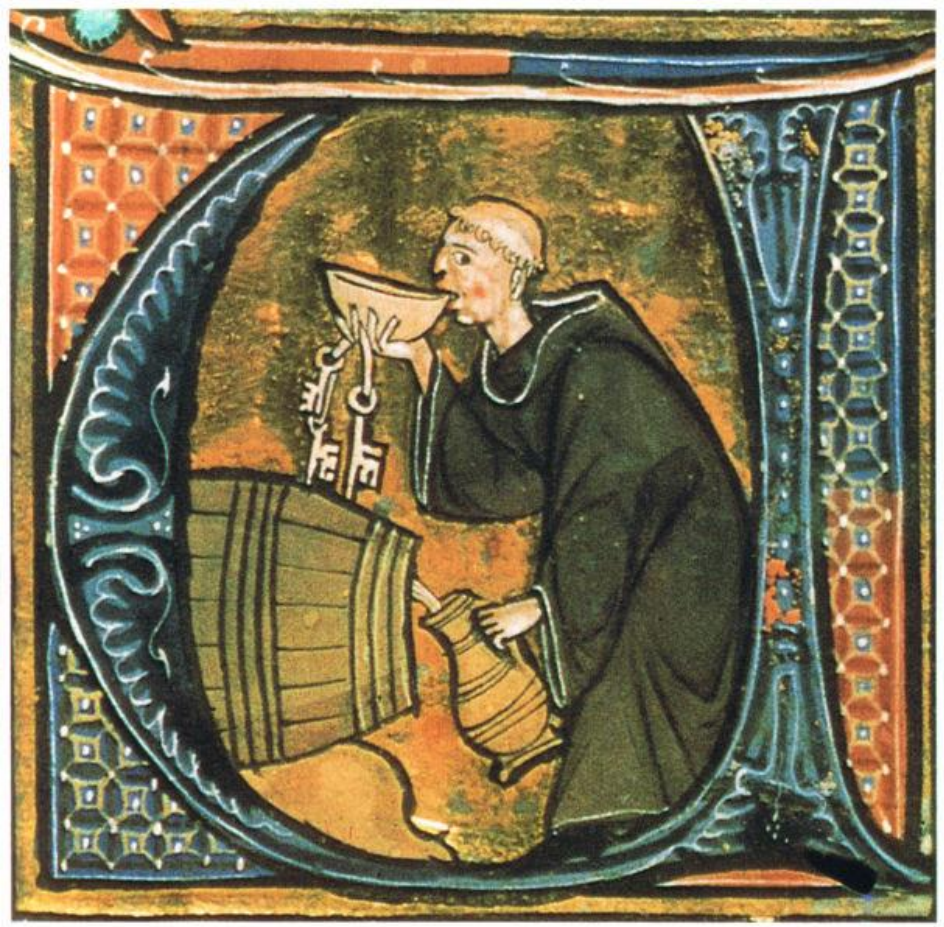

Monk sneaking a drink, Aldobrandino da Siena, Livres dou santé [Lives of Saints] (British Library, MS Sloane 2435), fol. 44v. PD-US-expired. (Source: https://commons.wikimedia.org)

RU: Well, even into the 1880s, spoilage rates (even in breweries) could be up to $10-20 \%$. This could be due to mistakes, or sometimes things just happen. It's easy for beer to become infected. In the eighteenth century, brewers would have young boys in the brewery who worked with sticks or wands to scare away the birds because after beer is boiled it had to ferment, and while it was cooling it became very susceptible to bacteria. Birds might fly, insects might come along and who knows what they might add to the mix. Anything might happen, and so keeping the operation sanitary is always an important question. And then once some 
kind of contaminant got into, say, a fermenting trough, or into a barrel, then it's extremely difficult to get rid of it. Brewers cleaned with hot water all the time. They tarred the insides of barrels too (though it would damage the taste) - anything to try to cut down on spoilage.

But really it was Pasteur who discovered what yeast was about. ${ }^{5}$ Controlling the yeast, controlling the temperatures, refrigeration machinery, which, by the way, was developed for brewers; they subsidized the development of refrigeration machines, experiments with them, and they bought some of the first models because they realized how important it was to their business. So then, by the 1880 s, between pasteurization, getting control of bugs and keeping it cold, beer became what we know now. It became a very different product. In the Middle Ages, people made it home and they drank it pretty quickly. I'm told that in West Africa that that's still the case. You make it and then drink it by the next day. Because of the warmer temperatures the fermenting beer is the type of environment that small bacteria just love! All the nutrients there, a nice warm environment - great stuff. So, that was what brewing was like. You couldn't keep it around for very long until it went bad. The way to preserve many foods was to let them ferment. Wine is the way to keep grape juice for a while. Cheese is a way to keep milk edible for a while, same with yogurt. And beer was a way to - by increasing the alcohol content - make grain last longer. Hops can be used to fight a lot of bacterial infection. Hops were used in a way to make beer - certainly in the Early Middle Ages - hops were used in beer making in monasteries, it looks like. The archaeology suggests that.

Somewhere around 1200, brewers in Bremen in north Germany figured out the right balance in the hops and all the other ingredients. Hops were expensive. They probably over-hopped the beer. That's true of craft brewers in the twenty-first century too. Sometimes you have an IPA with so many hops in them that you can't taste anything else. It's overpowering. But north German brewers figured out this method to keep it good for six months at a time. And that meant you could store it, you could ship it, you could invest in it, then wait around. You could brew in March and then wait through July. Every day that it sits there,

5 This was Louis Pasteur (1822-1895), renowned French biologist whose discoveries on microbes shed light on processes such as vaccination, fermentation, and, strangely enough, pasteurization. 
there's a chance that it might go off. But I would say by June you could still drink the hopped beer, that is over a period of time and even over a geographical area, if you shipped it somewhere else. Hopped beer makes its appearance, according to some people, in the tenth and eleventh centuries. By the fifteenth-sixteenth centuries, it appears all the time. In fact, wine consumption goes down, and beer consumption goes up. In England, by the fifteenth century, you start to get beer with hops, and it gains popularity. Before that the drink was ale, which is the same drink made without hops - at least that's how it was in the sixteenth century. The area of hopped beer drinking spread east and south to Normandy. The region where hopped beer prevailed varied a lot in the fifteenth and sixteenth centuries.

CM: I can imagine!

RU: Yes, indeed. The same is true with Bohemia. These places had beer, but it was the introduction of hops that made it a really popular drink.

CM: In Germany, I think monasteries played a very important role. You go to a German supermarket, and you will see an Augustiner, a Franziskaner, or in some cases they're named after particular saints. Jägermeister has the image of Saint Hubert on it, ${ }^{6}$ and so does a Hungarian liquor called Hubertus. Before we go to break, I did want to ask a little bit about the alewives. In The Book of Margery Kempe, ${ }^{7}$ which is a delightful source of many and wonderful things, one of the things she talks about in her early life is how she tried to make it both as a miller and as a brewer. I can't speak for other parts of Europe, but in England you get a sense that a lot of people doing the everyday family brewing ended up being women. There are special sermons about how alewives should not cheat their customers and things like that. Can you say a little more about the women involved in the brewing process?

\footnotetext{
${ }^{6}$ Saint Hubert (d. 727) was the bishop of Liège associated with a legend that he was a hunter in his youth and was converted by the sight of a stag with a crucifix between its antlers. This explains the symbolism on a bottle of Jägermeister.

${ }^{7}$ Margery Kempe (c. 1373-1438) was a mystic from England whose invaluable book, detailing spiritual visions and pilgrimages, also sheds much light on the life of ordinary women and society in her period.
} 
RU: Margery Kempe is not a great example of what to do. Probably another instance of a person I don't think I would have liked to travel with.

CM: No indeed.

RU: She ended up growing her own business, but it had nothing to do with the job. It wasn't a hands-on type of job for her. And that was possible, and people could try their hand at brewing, and some of them were women, though in the sixteenth century that wasn't as common. Typically, in the thirteenth and fourteenth centuries women were the typical brewers. Hops come along in the fifteenth and breweries become big operations in cities. When large-scale brewing starts, it's mostly done in monasteries. In the high Middle Ages, though, most people would get their beer from a woman in a village or in their town who had space to make beer. It was like baking bread. Women would make it and then sell it. This was a task for single women who had no land and who needed some income. Or brewing was the task of alewives, who were the wives of better-off farmers who had the capital and the time and the cash to buy the ingredients. Those alewives would indicate that there was beer available. People would come into or outside their houses and drink what could be had, drinking it out of their own cups. And there was always a suspicion that these women were up to no good and were skimming on the measure or watering it down. Accusations like that are being made public in the sixteenth and seventeenth centuries.

CM: Same for bakers as well... The Middle Ages is not a period where they liked bakers from my understanding.

RU: That's very true. Bakers and brewers would share yeast, for example. Big monasteries - there are examples from the ninth to the sixteenth century, where the bakery and the brewery would be next to each other.

CM: That sounds sensible.

RU: They would share the heat. They would share some implements. They were related trades. 


\section{Medieval Trade and the Pirenne Thesis}

CM: One of the things that I think has really been central to a lot of what we've been talking about this interview has been the question of trade movement of objects in space and (to a lesser extent) time and its role in economic growth. Would you mind telling us a little about your particular interest in trade in the Middle Ages?

RU: The problem with talking about exchange, especially exchange over any distance, is that it was so small. There's very little of it. When you compare it to the total production of the economy (which is what we do because we have statistical offices for every country and they produce all kinds of data), then it really comes out as a very minute portion of what went on. I would be surprised if trade were ever as much as $10 \%$ of the total of the economy in medieval Europe. Of course, in some places trade mattered more and sometimes trade mattered more. In the Early Middle Ages, there's almost none of it. I mean, there are traders around. There are a few. The fact that there are Vikings means that there must be some sort of trade, otherwise they would have had nothing to steal. The presence of pirates means that there is commerce, and sizable commerce because not only do pirates need some source of commerce but continuing commerce so they can continue to steal. It looks like Vikings would trade sometimes, while at other times they would take to stealing. Some were specialists in raiding, but some also did both and would shift comfortably from one to the other. In the Early Middle Ages, it's very much a minority activity. But in part because of improvement in ships, partly because of the rising population, partly increasing urbanization, partly because of the establishment of this gigantic Arabic Empire stretching all the way from Spain to India, which had extensive commerce moving back and forth through the Empire, by land and by water, European trade revived. It expanded and grew from the middle of the tenth century on.

CM: The Pirenne thesis?8

${ }^{8}$ Henri Pirenne (1862-1935) was a Belgian historian, whose thesis saw the origin of the Middle Ages in shifts in trade brought about by Islamic expansion. It has been accepted, challenged, and debated over the decades by medievalists. 
RU: He thought that the disappearance of trade was the reason for the end of the Roman Empire, and he thought Muslims cut off trade. The odd thing is that after, well let's see, the book came out in 1937, English translation in '39, and almost immediately there was a barrage of criticism on almost every aspect, not so much the theoretical side, but on almost every bit of evidence he produced. By, say, 1980 no one believed the Pirenne thesis at all anymore. Except everyone still keeps talking about the Pirenne thesis! It's always lurking in the background, and even those people who have no use for it and know it's wrong still have to come to terms with it in one way or another. Probably because a lot of research has been done inspired by it because he made trade and communication a central issue about early medieval European history. Behind it is the idea that trade causes regular contact and therefore the transmission of culture and political practices, all kinds of information. Without that, political structures cannot be sustained. People just don't know about each other, and so they can't form any common bonds. It's not clear that you need communication to create empires, but it certainly helps for economic growth. It certainly helps to create a rich, vibrant, varied culture. We know about that because we have greater communication now than ever in the past. In fact, we're overloaded with it!

This was not a problem in the Middle Ages. It's certainly true that from the tenth century on - starting in the Muslim world from the eighth century on - along the northern shores of the Mediterranean from the tenth century on. The expansion of trade over time moved further north. In the eleventh and twelfth centuries in Northern Europe, there was much more commerce. And that meant that people had access, first of all, to luxury goods from far away, but also, increasingly, goods that were used every day. By the thirteenth century, there are ships carrying grain from Denmark and the Baltic to England - not enough to feed everybody, but enough to make sure that when times were bad there was some extra, some surplus, some cushion. So, it helped to cut down on shortages and also created greater variety. I think that's the most important point. Variety, first of all, in goods, and then variety in ideas.

The example I use most often is Geoffrey Chaucer, who was a poet and students of English Literature at almost any level have read The Canterbury Tales. The Canterbury Tales were modeled after The Decameron by Boccaccio. How is it that Geoffrey Chaucer, living in London in the second half of the fourteenth century, knows about Boccaccio? The 
answer is twofold. He worked for the king of England as a toll collector, working in a customs system that was established by Italian bankers at the end of the thirteenth century. Italian bankers had been brought to England because the English knew that the Italian towns had taxation systems that were highly effective, and the king of England wanted to borrow money from those Italian bankers who had made money in trade. The bankers said, "Sure, we'll loan you the money, but we'll set up this customs system, and we'll use the money we collect to recover the debt." That was all well and good, but the king recognized that it was better if he collected the taxes. Then he could decide how much he could pay the Italian bankers - or not. A couple of Italian banks broke in the middle of the fourteenth century because of the king failing to come up with the money he said he would give them.

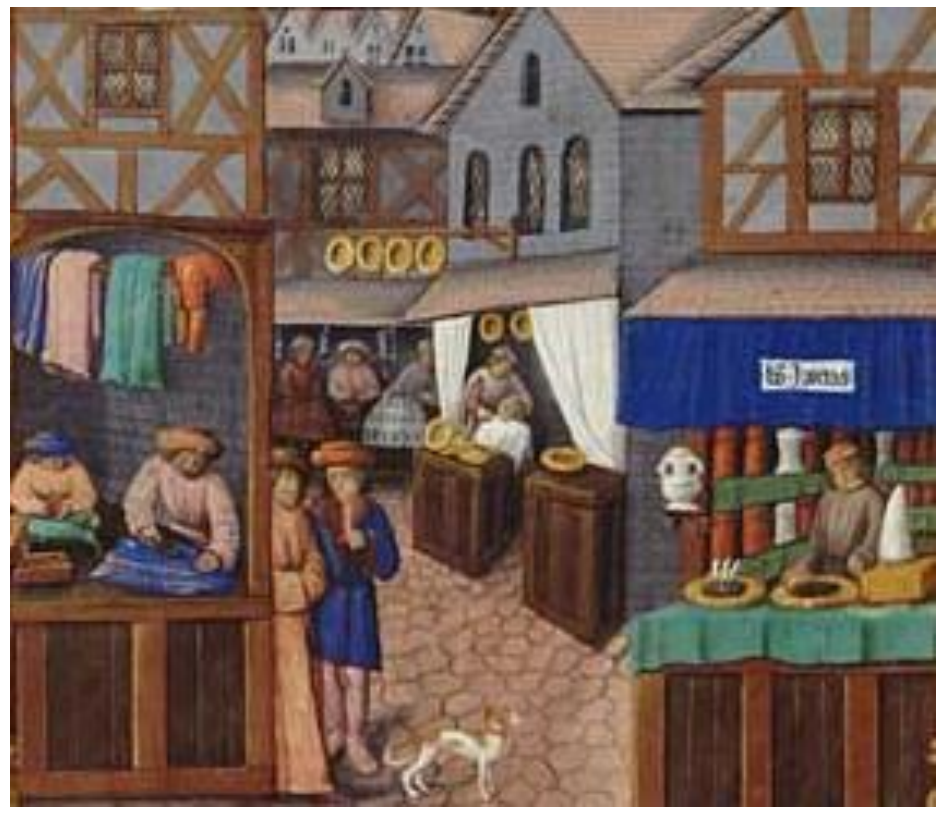

A medieval market street, fragment, Romain Gilles, Livre du Gouvernement des Princes [Book of the government by Princes], sixteenth century

(Bibliothèque nationale, Paris) fol. 149v. PD-US-expired.

(Source: https://commons.wikimedia.org) 
CM: It's good to be the king.

RU: Yes. So, Chaucer had gotten his day job because of commerce and trade, and he also got to know Italian merchants. He picked up languages, which is not all that uncommon, but with trade it made it a lot more advantageous for him to know French and Italian. And he was sent to Italy twice on diplomatic missions for the king. So, this commerce, the flow of goods back and forth between the Mediterranean and England started around 1270-1280 when - and here we go back to ship design when ships got good enough to make it in and out of the Mediterranean, and there was regular trade between the north and south. That flow of goods and the flow of information and knowledge under the establishment of this customs system, which led to Chaucer's job and Chaucer knowing about the literature of the day made it possible for him to - exploit may be too strong a term... - be influenced by Italian and French literature. And because of these trade connections, this cultural exchange became greater and greater over time, stretched by the end of the Middle Ages to the Far East and to the New World.

CM: In Canterbury Tales, there's so much going on there, and I think in terms of the international character. I always think of the three - they're either cloth merchants or dyers - that have some sort of trade in fabric. And one of the points that Chaucer makes when he's poking fun at them is that their wives always insisted upon being called "Madame." It wasn't good enough to be Mrs. Dyer or Mrs. So-and-so. It had to be Madame. In connection with those sorts of international connections, I think it is something that - I know that in Hungarian towns, there's a very large bilingual portion (German and Hungarian) in places like Buda in particular, and it's always fun to think about these communities intermingling. There was a former CEU student [Olha KozubskaAndrusiv] writing about Lviv, which is now in western Ukraine, how in the Middle Ages there would have been a "Latin" community, an Armenian community, a Greek community, all these different communities in this one city way out east.

RU: That's absolutely true, and that would have been true in many places. In fact, probably everywhere urban populations would have been mixed, and there would have been a number of languages spoken. At what level 
is another question. These are not people sitting down talking about the nature of the universe. Astrophysics is not the usual topic while you're drinking a glass of beer (or wine, depending on where you are). But yes, the other thing (speaking of Madame Dyer) is that trade and exchange meant that industries could develop. They could be at a certain scale if the market was large enough. They could grow at a certain size and be centralized and be more efficient. So that meant that in these cities, there were a variety of people. Widows and indeed single women made up a significant portion of the population of cities because at least there might be some poor relief for them. There might be some accommodation. There might be some support system for them. But also, day-laborers who had no land, farmers who had plots outside the town who would go out and work them. So, in that sense it would be like a village agricultural laborers who would work by day but also farmers who could own land or who leased land. And then tradesmen, skilled workers, merchants, and noblemen - titled people who were landowners themselves, who leased out land to farmers. So, towns would have had a broad range of population, whereas in most villages it was less so. However, that is not to say that most villages didn't have gradations. There were rich farmers, not so rich farmers, poor farmers, the landless workers. So, the variety in cities, the extent and range of the social differentiation and the extent and range of income and political interests was much greater, and it grew with exchange and trade. So, the repercussions for culture, for politics, for society in general, for languages, almost every aspect of the lives of these folks were affected by the extent and range and character of trade encounters.

CM: And most trade and commerce - it's just a thought that came to me, but I think it's a point that needs to be clarified - most trade and commerce, in my understanding, would have gone either through rivers or by sea. Was it easier to do it that way?

RU: Oh yeah. The physics of the bodies in question; there's a lot less friction between the hull of a boat and the water than there is between the wheel of a cart and the road. Because there is less friction, it takes less energy to move the boat around. One of the problems that folks had until the development of the steam engine in the late eighteenth century is that they really didn't have ways to move things over any distance. They 
had to carry them or have an animal carry them, put them on a wagon that was pulled by animals, or put them on a boat. Boats just took a lot less effort. That being the case, the cost of moving goods was going to be less over the water. Wherever there was water, the chances of trade and exchange were much greater. It's surprising that there was evidence of requisitioning supplies for the English army in the Hundred Years' War, ${ }^{9}$ in which they would get food from the most obscure, backwoods place because there was some kind of creek. It might only be about a meter wide, but at least they could get a boat up there. So, they might collect some grain and take off, then go downstream, which led to a small river and that led to a bigger river, which led to a port town, and from there it would be shipped off to France. And that was a fairly typical pattern.

CM: I don't know much about land routes, but one of the things that I do remember from reading years ago - this is in relation to the wine trade in medieval Hungary - that on the land route from Buda to Cracow that there would have been ten different places along that route to pay tolls where tolls were required to enter in and out of the city. Would there have been similar types of tolls for sea travel?

RU: That's another advantage of going by water. Along the rivers, there would be people who had their hand out for money. Along the Rhine, from the Early Middle Ages to the High Middle Ages there were lots of castles where local lords would be down there with their lads to collect small amounts of money. That's wonderful, of course, for historians because you have records for what goods were shipped out and maybe some idea of how much. At sea, there would be fees at departures, certainly at arrivals collected by people like Chaucer, but that was it. Whereas on land routes, there's always the possibility that you go around the corner, and there's somebody there who would charge you for a toll. The tolls would increase if a local could establish a tradition of collecting a toll, even if he had no reason or right to it. If it was established practice, that was enough. So, the number of tolls increased over time through the

${ }^{9}$ The Hundred Years' War (1337-1453) was fought between France and England for over a century. The motivations for war were partly dynastic and, on the basis of this interview, one might surmise that they were largely economic. 
Middle Ages. People who collected tolls were smart enough to realize that if they charged too much, they would kill the goose that laid the golden egg. They wanted to make enough pay, so they'd have to choose exactly how much they were going to charge. The end result was that somebody was going to have to pay it and that would be the consumer at the other end. So, it was a barrier to royal authority. Kings, especially in Central Europe - well, I take that back; in Central and in Western Europe - were really in no position to or had little interest in suppressing those tolls. Often, they charged them themselves. In Italy there was no general overarching government authority - each city-state had its own tax-structure, which was the model for the rest of Europe, so they kept their tolls. Internal tolls did hurt trade, they prevented trade, they slowed trade - even though they were a welcome revenue source for whoever was charging them.

\section{Richard Unger and the Medieval Academy of America}

CM: One of the things I understand about your career is that until very recently you were the president of the Medieval Academy of America. Is that correct?

RU: That's right. I was president for a year and vice president for two years. I stepped down in April of this year, so it is very recent. ${ }^{10}$

CM: Unless there's a secret or a statute of limitations or anything like that, could you tell us a little about your time as president? I'm very curious about that.

RU: Well, it was a very steep learning curve. There was a lot to be done. We had been moving in this direction for some years, and a lot of talk was about how to structure the organization. So, we made some adjustments, separating out the job of editor of Speculum, the journal of the academy, and, in a sense, the journal of record of medieval studies. It's a place where (I think more so now, thanks to our editor) you can go to see what's going on in medieval studies and what new kinds of work are being done. The journal is interdisciplinary. Many of the articles are

10 This interview was conducted in June 2014. 
interdisciplinary, and there's an extensive review section. If you can get through all of those reviews, then you really do know what's going on in medieval studies. Then we also have a different sort of structure for the executive director who's responsible for maintaining the organization and making sure that grants are administered properly, and membership services are maintained. For the academy graduate students make up something like $20 \%$ of the membership, a number which surprised me. I'm very pleased by it. Most of the members are in the United States, some of the members are in Canada, and a few in Europe and in Asia. So, it's an international organization. Graduate students find that there's some value in belonging, not only because of the journal, but also because of the activities of the graduate student committee, which has receptions at international conferences and also has a mentoring program that puts graduate students in touch with people who are practicing in their field. The academy also offers various kinds of financial support for graduate students. There are extensive grants for travel to conferences, for research in the field, the doctoral fellowship grants. In fact, there is a new graduate fellowship which will be instituted this year, so the number keeps growing. The organization is committed to the support of new young scholars in the field. And there's an annual meeting, where we get together and talk among each other and about what's going on. We have a lot to say about everything. So overall, it's a thriving organization, which is going to grow. This is going against the trend because, of course, these are not good days in the academic world, as anyone involved can tell you. Things have been better. But the academy looks like it's in good shape, and a good avenue for the support and expansion of medieval studies - not only in the United States but also in Europe and even in China and Japan.

CM: I must say that I've been very impressed with the track record for Speculum in terms of the wide variety and the actual commitment to interdisciplinary research which, in my own experience, there's a lot of lip service about. Interdisciplinary research - sometimes, when push comes to shove, you get the response, "Well, that's nice, but that's really more of a history topic. Why don't you go tell the history people what you're doing?" "Well, the history people told me to come here in the hopes that you might help me out." That's very good to hear. 
RU: Yes, I think that the editor of the journal has said that she would be interested in seeing more submissions. She may come back and say, "Look, this is really history," or be very interested in seeing what's going on and say, "Alright, this is history, but let's see what we can do." And there's a board, an editorial board, which will read the papers and send them out to readers. They're glad to help get papers into shape for Speculum, or they'll prepare them for another journal where they might be more suited. So that's another thing that the journal and the organization can do - not only for young folks starting out in the trade, but also us old guys out there too.

CM: Very good! Well, Dr. Unger, thank you so much for joining us at CEU Medieval Radio today.

RU: And thank you! It's been a pleasure. 